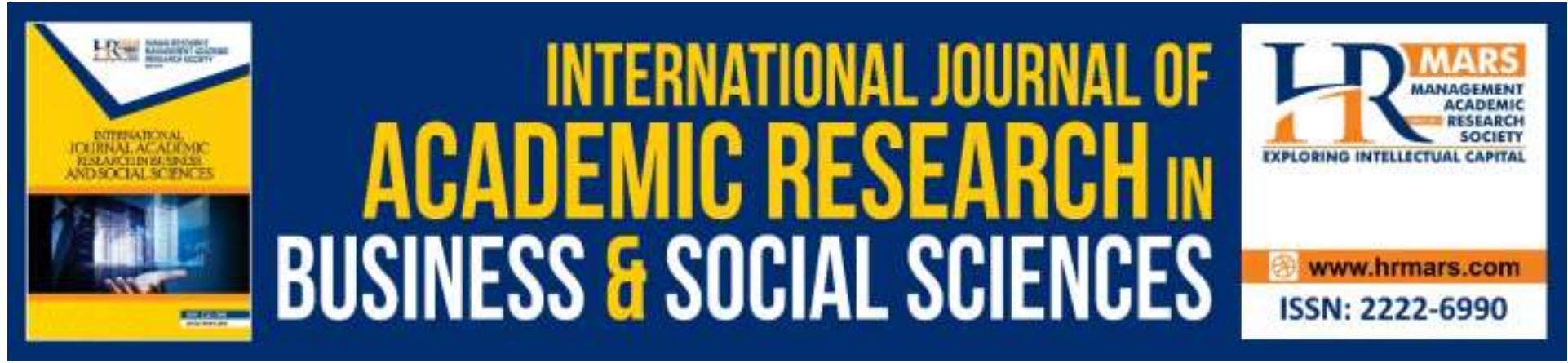

\title{
The Determinants of Student Commitment and Student- Institution Engagement in Malaysian Higher Education Institutions
}

Juliana Osman, Zuraidah Zainol, Rusliza Yahaya \& Norlaile Salleh Hudin

To Link this Article: http://dx.doi.org/10.6007/IJARBSS/v9-i7/6192

DOI: $10.6007 /$ IJARBSS/v9-i7/6192

Received: 25 May 2019, Revised: 27 June 2019, Accepted: 03 July 2019

Published Online: 30 July 2019

In-Text Citation: (Osman, Zainol, Yahaya, \& Hudin, 2019)

To Cite this Article: Osman, J., Zainol, Z., Yahaya, R., \& Hudin, N. S. (2019). The Determinants of Student Commitment and Student-Institution Engagement in Malaysian Higher Education Institutions. International Journal of Academic Research in Business and Social Sciences, 9(7), 933-949.

Copyright: (C) 2019 The Author(s)

Published by Human Resource Management Academic Research Society (www.hrmars.com)

This article is published under the Creative Commons Attribution (CC BY 4.0) license. Anyone may reproduce, distribute, translate and create derivative works of this article (for both commercial and non-commercial purposes), subject to full attribution to the original publication and authors. The full terms of this license may be seen

at: http://creativecommons.org/licences/by/4.0/legalcode

Vol. 9, No. 7, 2019, Pg. 933 - 949

http://hrmars.com/index.php/pages/detail/IJARBSS

JOURNAL HOMEPAGE

Full Terms \& Conditions of access and use can be found at

http://hrmars.com/index.php/pages/detail/publication-ethics 


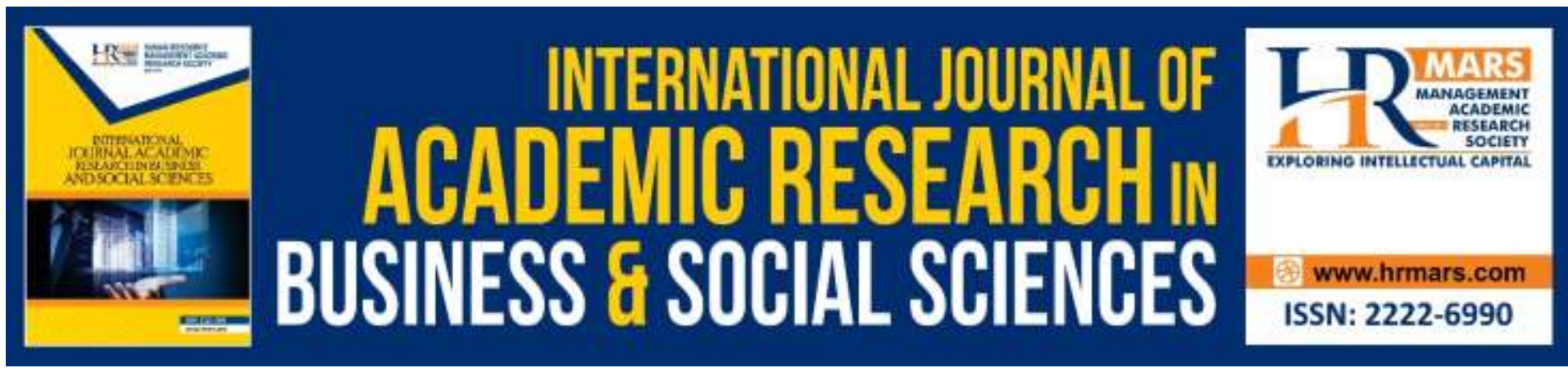

\title{
The Determinants of Student Commitment and Student-Institution Engagement in Malaysian Higher Education Institutions
}

\author{
Juliana Osman, Zuraidah Zainol, Rusliza Yahaya \& Norlaile \\ Salleh Hudin \\ Department of Business Management and Entrepreneurship,Faculty of Management and \\ Economics, Universiti Pendidikan Sultan Idris, Malaysia \\ Email: juliana@fpe.upsi.edu.my
}

\begin{abstract}
This study aims to identify the determinants that may provide the public and private HEls with a competitive advantage in recruiting, retaining and engaging the students. Specifically, this study examines the effect of student satisfaction, dimensions of relationship investment and alternative attractiveness on student commitment, and consequently on the student engagement across public and private HEls. To test the proposed framework, this research adopted the positivist, quantitative and deductive approach. Data were gathered using questionnaires from a sample of 300 public and private HEls students and were analyzed using multi-group analysis in Structural Equation Modelling (SEM). The results show that in order to increase the student engagement, both the public and private HEls should increase the student commitment and accomplish similar strategies that are to focus on student satisfaction and student direct investment. In spite of that, it is important for the private HEls to focus on the institution social investment. This study provides understanding of how students can be retained and consequently guides the public and private HEIs in building stronger relationships with the students to achieve sustained competitiveness and survival in the industry.
\end{abstract}

Keywords: Relationship Investment, Student-Institution Engagement, Higher Education Institutions

\section{Introduction}

Malaysia envisioned to be a centre of education excellence and a hub for higher education in the Southeast Asia region. Rapid expansion of higher education can be seen in the nation, especially with the increased number of Higher Education Institutions (HEls). Based on the statistics released by the Ministry of Education, despites the number of public HEls remain at 20, the number of private HEls has increased significantly from only 49 in 2010 to 486 in 
2014 (Ministry of Education Malaysia, 2014). The rapid development of private HEls is to accommodate the increase in student enrolment in HEls (Bajunid \& Wong, 2016).

The number of students enrolled in Malaysian private HEls has increased substantially from to 2014 to 2016, as shown in Table 1. On the contrary, the students' enrolment in public HEls has decreased during the same time range. More importantly, the students' enrolment in private HEls is higher than in the public HEls for two consecutive years that are in 2016 and 2017 (Ministry of Education Malaysia, 2017).

Table 1: Number of Students' Enrolment

\begin{tabular}{|l|c|c|c|c|}
\hline & $\mathbf{2 0 1 4}$ & $\mathbf{2 0 1 5}$ & $\mathbf{2 0 1 6}$ & $\mathbf{2 0 1 7}$ \\
\hline Public HEls & 563,186 & 540,638 & 532,049 & 538,555 \\
\hline Private HEls & 493,725 & 493,926 & 595,347 & 565,852 \\
\hline Total & $1,056,911$ & $1,034,564$ & $1,127,396$ & $1,104,407$ \\
\hline
\end{tabular}

Source: Ministry of Education Malaysia (2017)

The figures apparently support the notion that private HEls now play crucial roles in the development of Malaysia's higher education in contributing towards becoming the international hub of higher educational excellence and providing adequate education opportunities (Bajunid \& Wong, 2016). With more private HEls available in the local and global markets, students have more options of good education opportunities. With the rising power to choose any educational institution that perfectly matches their needs and wants, there is a high tendency for the students to become very demanding and switch to an alternative institution with better offering.

Accordingly, in order to win new students and retain existing students, all HEls are challenged to design better offering that can penetrate the local and global education market. That is, every HEls must ensure the relevance and competitiveness of their offering with respect to the development of knowledge as well as the local and global market needs. To achieve sustained competitiveness, marketing scholars have long raised on the significance of developing and maintaining stronger relationship with customers, rather than focusing on short-term measures including price, quality and satisfaction (Alqahtani, 2011; Carter, 2008; Circles, 2010; Hess \& Story, 2005; Louis \& Lombart, 2010). It has been highlighted that strong customer engagement will drive the customer willingness to exhibit brand supporting behaviours including making larger purchases, greater commitment and loyalty, positive word-of-mouth and active recommendations (Bowden, 2007; Circles, 2010; Roberts \& Alpert, 2010; Sashi, 2012; Tripathi, 2009), and become the passionate advocates of a brand even in good or bad times (Ginman, 2011; Sashi, 2012). Thus, adapting this understanding to the context of the competition among the public and private HEls, it may no longer suffice for the public and private HEls to keep on competing in terms of education fees, quality and satisfaction to strengthen their offering but to move forward by building a stronger relationship with students. In another word, it is critical for the public and private HEls to not only make the offer more desirable, attractive and preferable to the students but also do 
whatever it takes to make the students to remain associated, interested and involved with the institutions.

Much research has been done to understand the Malaysian public and private HEls. However, most of the studies are either conceptual in nature or focusing on identifying factors influencing students' selection of HEls. Limited research has studied the marketing issues in Malaysian HEls, particularly in branding aspect as well as relationship marketing. Given the limitation in the existing literature, and the rising needs to ensure the relevance and competitiveness of the HEls's offering, a study examining the student-institution engagement across the public and private HEls in Malaysia is needed. Hence, this study compares, (1) the effect of satisfaction on commitment, and consequently on the student engagement between the public and private HEls, (2) the effect of dimensions of relationship investment (student direct and indirect investment, and institution economic and social investment) on commitment, and consequently on the student engagement between the public and private HEls, and (3) the effect of alternative attractiveness on commitment, and consequently on the student engagement between public and private HEIs.

\section{Literature Review and Hypotheses Development}

Previous studies, which adopted the Rusbult's Relationship Investment model, have confirmed the significant effect of satisfaction, investment size and alternative attractiveness on commitment, in which the commitment is strengthened by satisfaction and investment size, but weakened, by alternative attractiveness (Breivik \& Thorbjornsen, 2008; Li \& Petrick, 2008; Sung \& Campbell, 2009; Sung \& Choi, 2010). Satisfaction can be defined as "a consumer's affective state resulting from an overall appraisal of his relationship with a retailer, trust as "a consumer's confident belief in a retailer's honesty towards the consumer" (Kristof De Wulf, Odekerken-Schroder, \& Kenhove, 2003, p. 11). Following de Wulf, et al. (2003), satisfaction can be referred as a student's attitude towards HEI resulting from his/her overall appraisal of the relationship with $\mathrm{HEl}$. Commitment refers to "a consumer's enduring desire to continue a relationship with a retailer accompanied by this consumer's willingness to make efforts at maintaining it" (Kristof De Wulf, et al., 2003, p. 11). Following de Wulf, et al. (2003), student commitment can be regarded as a student's enduring desire to continue his/her relationship with $\mathrm{HEI}$.

In human interpersonal relationship context, Rusbult (1983) proposed Relationship Investment model, in which relationship investment serves as one of the predictors of relationship commitment. In the model, relationship investment is defined as the resources attached to a relationship, which would be lost or seriously diminished if the relationship were to end (Goodfriend \& Agnew, 2008; Le \& Agnew, 2003). Instead of looking into the investment made by both parties involved in a relationship, the model only considers the individual perception of his/her own relationship investment in influencing the means of an individual becoming committed to a relationship end (Goodfriend \& Agnew, 2008; Le \& Agnew, 2003; Rusbult, 1980, 1983; Rusbult, Martz, \& Agnew, 1998). Formally termed as investment size, individual own relationship investment is operationalized as "the magnitude and the importance of the resources attached to a relationship" (Rusbult, et al., 1998, p. 359). In other words, it refers to the individual perception of how much and how important of his/her own investment in a relationship. 
Realizing the applicability of the Rusbult's Relationship Investment model, many of the business-based studies have adopted the model. Following the model, relationship investment is termed as investment size. In particular, to describe the business-to-business (B2B) relationship, investment size is defined as "the degree of the invested resources for maintaining the long-term relationship" (Huang, Cheng, \& Farn, 2007, p. 754) while in the business-to-customer (B2C) context, investment size is operationalized as "how much that customers have already invested in a relationship" (Nusair, Parsa, \& Cobanoglu, 2011, p. 835). Besides, in several B2B studies, other terms are used to refer to relationship investment. The terms include relational-specific investment (RSI), which refers to "the extent to which exchange members undertake tangible or intangible investments in a specific inter-firm partnership such that the investments will lose value unless the relationship continues".

A study by Rusbult (1980) highlighted that larger intrinsic and extrinsic investments produce greater commitment, which consequently leads to relationship continuity (Yu, 2015). Although Nysveen, Pedersen, Thorbjornsen and Berthon (2005) revealed that only direct (intrinsic) investment serves as a significant predictor, the subsequent study by Moon and Bonney (2007) strengthen the previous findings by pointing out that both intrinsic (direct) and extrinsic (indirect) investments play a significant role to influence commitment. Thus, it could be expected that student direct and indirect investment play a major role to affect student commitment. Accordingly, it may be posited that

$\mathrm{H} 1$ : The positive influence of student satisfaction on student commitment differs significantly across public and private HEls.

$\mathrm{H} 2$ : The positive influence of alternative attractiveness on student commitment differs significantly across public and private HEls.

H3: The positive influence of student direct investment on student commitment differs significantly across public and private HEls.

H4: The positive influence of student indirect investment on student commitment differs significantly across public and private HEls.

Based on Social Exchange Theory and Signalling theory, de Wulf et al. (2001) propose the Relationship Exchange model, which perceived relationship investment is posited as a mediator in a relationship between relationship marketing efforts and relationship quality. In the model, which focuses on the consumer-retailer relationship, perceived relationship investment is defined as " $a$ consumer's perception of the extent to which a retailer devotes resources, efforts, and attention aimed at maintaining or enhancing relationships with regular customers" (De Wulf, et al., 2001, p. 35). Basically, it refers to an individual's perception of the extent to which his/her partner in a relationship has actively made efforts that are intended to retain the customers. With regards to the student-institution relationship, perceived relationship investment can be regarded as the student's perception of the extent to which the Higher Education Institution (HEI) has actively devoted resources and made efforts that are aimed to retain the student in a relationship with an institution (Aurier \& de Lanauze, 2012; Kim, Kim, Jolly, \& Fairhurst, 2008; Wang \& Head, 2007). Hence, in this study, perceived relationship investment is better termed as a perceived institution investment. 
This research adopts two major dimensions of perceived institution investment i.e. economic and social investment. Institution economic investment (IEI) is defined as the student's perception of the institution's efforts aimed at building functional connections, which such efforts are easily traced financially and less personal in nature; whereas institution social investment (ISI) as the student's perception of the institution's efforts aimed at building emotional connections, in which such efforts are hardly traced financially and more personal in nature (Bolton, Smith, \& Wagner, 2003; Dorsch, Carison, Raymond, \& Ranson, 2001; Morais, Backman, \& Dorsch, 2003; Morais, Dorsch, \& Backman, 2004).

In addition, past studies revealed that perceived relationship investment has been established as a significant predictor of commitment (Aurier \& de Lanauze, 2012; Odekerken-Schroder, De Wulf, \& Schumacherc, 2003; Shi, Shi, Chan, Liu, \& Fam, 2011). Hence, the findings justify that when the customers perceive that the partner has made significant attempts to maintain or enhance a relationship with him/her, they are more likely to commit in a relationship. Despite little research on the effect of the dimensions of perceived relationship investment, Bolton et al. (2003) showed that both partner social and economic investments will promote the customer to respond more favourably to the relationship.

Furthermore, they also highlighted that the effect of the social and economic investment might differ significantly. In particular, investment in social resources has a greater influence on customers' interpersonal satisfaction with the company representatives and perceived value, while investment in economic resources has a stronger effect on customers' overall satisfaction with the organization. Further, they added that the role of social investment could transcend economic investment, which it creates stronger bonding to the extent that the emotional bonding developed could compensate the lacking in the structural bonding. Thus, it could be asserted that both economic and social investments play a significant role to trigger the customer to value the relationship more favourably, but the effect of social investment might outweigh the economic investment. Thus, based on all the above findings, it could be expected that both institution's social and economic investments will have a positive influence on the relational outcome. Therefore, it could be assumed that

H5: The positive influence of institution economic investment on student commitment differs significantly across public and private HEls.

H6: The positive influence of institution social investment on student commitment differs significantly across public and private HEls.

It has been established that customer engagement is essential for companies to win and retain the customers (Circles, 2010; Forbes, 2010; Sedley, 2010; Voyles, 2007), but there is no universal definition of customer engagement adopted so far. From a general perspective, customer engagement is defined as "the degree to which a company succeeds in creating an intimate long-term relationship with the customer" (Voyles, 2007, p. 2). Besides, customer engagement is defined as the emotional connection between a customer and the engagement object, including a company or a brand that will encourage larger purchases, greater commitment and loyalty, positive word-of-mouth and active recommendation (Circles, 2010; Forrester, 2008; Haven \& Vittal, 2008; Peoplemetrics, 2009; Roberts \& Alpert, 2010).

Taking the marketing perspective, customer engagement plays a significant role in the development and sustainability of customer-brand relationship (Bowden, 2009a; Brodie \& Hollebeek, 2011; Brodie, Hollebeek, Juric, \& Ilic, 2011; Hollebeek, 2009; Sashi, 2012; van Doorn et al., 2010; Verhoef, Reinartz, \& Krafft, 2010). In fact, marketing scholars assert that 
customer engagement outweighs the roles commitment in predicting the strength of an established customer-brand relationship (Bowden, 2009b; Sashi, 2012; Zainol, 2015). While commitment is frequently adopted to indicate the endurance of a relationship, customer engagement to a greater extent indicates the enduring as well as the intimacy of the relationship (Sashi, 2012; Tripathi, 2009). That is, customer engagement has the capability to reflect not only the customers' strong willingness to sustain a relationship, but also their deep intention to be intimately involved in a relationship to the extent that they are willing to act positively for the best interests of the partner (Haven \& Vittal, 2008; Singh, Kumar, \& Singh, 2010; Tripathi, 2009). Although the length of a relationship established would be sufficient to indicate the relationship strength, with additional insight on the depth of a relationship, customer engagement would provide better and more accurate explanation of successful customer-brand relationship (Carter, 2008; Sashi, 2012; Tripathi, 2009), particularly when emotions are at work.

In addition, in the Customer Engagement Matrix, it has been described that engaged customers are customers that not only make large purchases, but also make a positive review of the brand and promote the brand to other customers at every opportunity (Haven, 2007; Roberts \& Alpert, 2010). Not only that, they also recommend, participate, provide feedback and become the passionate advocates of a brand even in good or bad times (Ginman, 2011; Sashi, 2012). Besides, customer engagement is also described as achieving high relevance of brand to customers, strong emotional connection between customer and brand (Rappaport, 2007) and, customer's sustained attention towards a brand (Abdul-Ghani, Hyde, \& Marshall, 2011; Scholer \& Higgins, 2009), in which the positive state of mind will further drive the customer willingness to exhibit brand supportive behaviours including increasing purchases, remaining loyal, continuing investment and making positive recommendations (Sashi, 2012; Tripathi, 2009) as to sustain a long term intimate relationship with the relationship partners.

Given the significance of customer engagement to reflect the strong bond between customer and the engagement object to the extent that will induce customers voluntary action to support the existence of brand, it is appropriate for this study to put forward the roles of student engagement as an indicator of the level of student-institution relationship. Accordingly, in this study, student engagement is defined as the intensity of the student's psychological state characterized by the emotional connection, sustained attention, brand relevancy and commitment to an active relationship with Higher Education Institution (AbdulGhani, et al., 2011; Scholer \& Higgins, 2009).

Empirical evidence of the antecedents of customer engagement has been scarce. Based on the limited findings, it has been revealed that commitment is the strongest determinant of customer engagement (Flynn, 2012). Malciute (2012) also highlighted that commitment significantly affect all three engagement dimension, i.e. behavioural, emotional and cognitive. Accordingly, it could be hypothesized that

H7: The positive influence of student commitment on student-institution engagement differs significantly across public and private HEls.

Drawing upon the theories and literature, the hypotheses development is depicted in the research framework presented in Figure 1 below. 


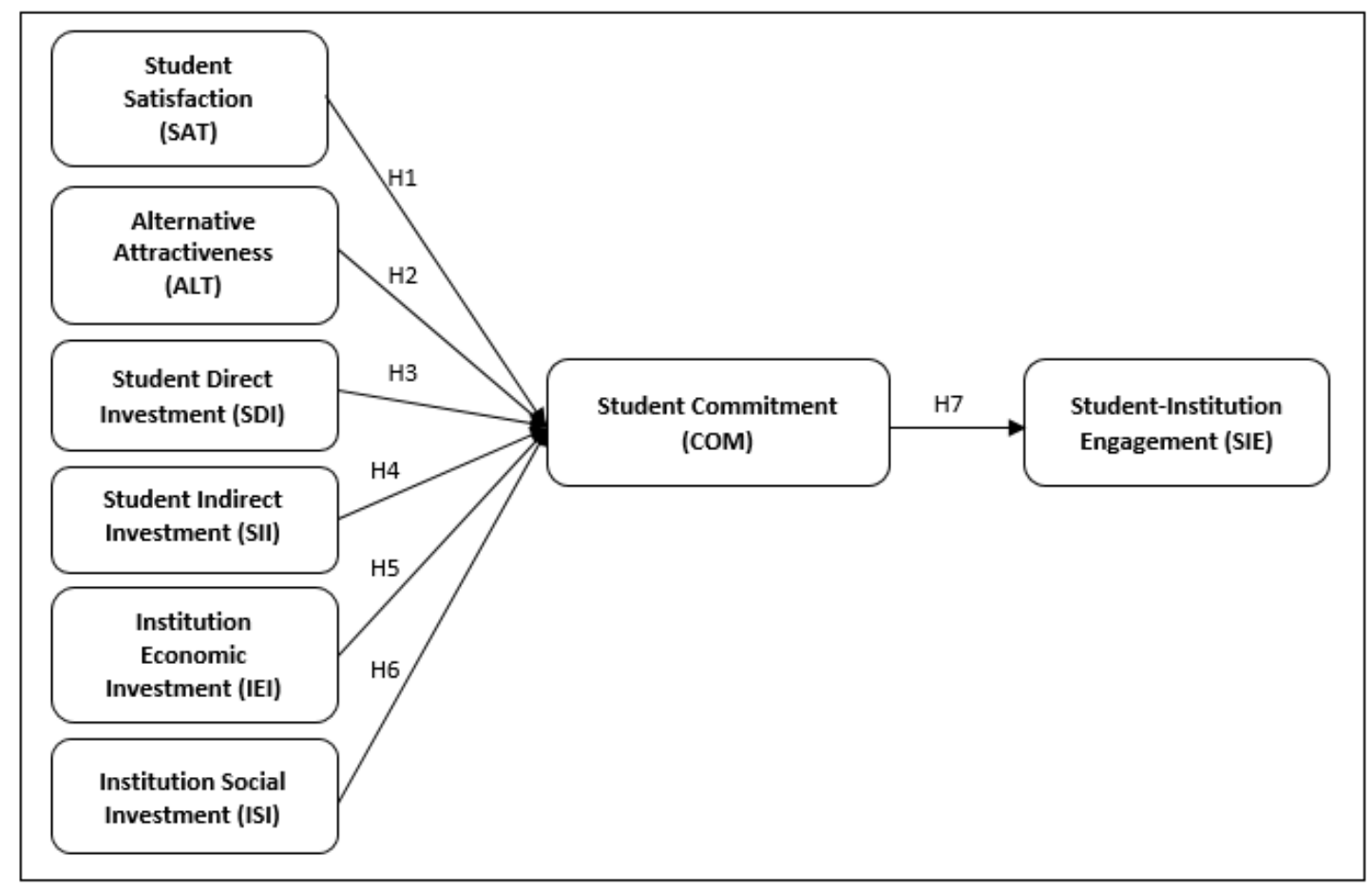

Figure 1: Proposed Research Framework

\section{Methodology}

\section{Research Design, Sampling and Measures}

This research adopts a quantitative and deductive approach as these approaches is applicable to empirically investigate the relationships among the underlying constructs (Creswell, 2009; N. K. Malhotra, 2009; Zikmund \& Babin, 2006). Survey strategy is used to collect data as it is economical in terms of cost, time and effort than any other strategies, and the most efficient tool in collecting data from a larger sample to produce generalized results (Bhattacherjee, 2012; N. Malhotra, Krosnick, \& Thomas, 2009; Saunders, Lewis, \& Thornhill, 2009; Shukla, 2008). As to verify the relationships proposed, the data is collected from each individual student in a natural environment or non-contrived setting with minimal interference of the students normal routine (Sekaran \& Bougie, 2016). Accordingly, the unit of analysis for this research is an individual student within the specific data collection period and setting (Bhattacherjee, 2012; Zikmund \& Babin, 2006).

The population of this study is all students in the selected public and private HEls in the West Malaysia. The total number of student enrolments in both the public and private HEls is 1,104,407 (Ministry of Higher Education Malaysia, 2007). For this research, students' evaluations as customers of the relationship factors that will induce them to engage are critical. As to ensure a valid and reliable evaluation from the students, this research considers only the existing students that possess some times of experience studying at the HEls (Mackenzie \& Podsakoff, 2012; Morais, et al., 2004). Given that six months is a good enough duration to enable the customer to give his/her true evaluation (Han, Kim, \& Hyun, 2011), therefore, the sampling frame of this study comprised students who have been studying in the HEls for more than six months or at least in their second semester. Specifically, using the street-intercept systematic sampling, 300 students who are at least in their second semester 
of studies were selected as samples. The data collection was conducted in four randomly selected higher education institutions (HEls)

A questionnaire with multiple items and seven-point Likert scale (1- strongly disagree to 7 strongly agree) was developed for all proposed constructs. All the 53 measurement items used were adapted from the extant literatures and, slightly modified to ensure the appropriateness in the institution-student relationship context. Specifically, items to measure institution economic investment (IEI), institution social investment (ISI), student direct investment (SDI) and student indirect investment (SII) were adapted from Zainol, Yasin, Omar and Hashim (2014). The satisfaction, alternative attractiveness and commitment are measured using Sung and Choi (2010), Rusbult et. al. (1998) and Fullerton (2011), respectively. Student engagement is measured using the scale adapted from Cheung, Lee and Jin (2011).

\section{Analysis Procedure}

Prior to actual survey, a pilot study was conducted with experts and potential respondents to identify any potential problems with the questionnaire. To ensure the validity and reliability of the measurement, the Exploratory Factor Analysis (EFA) and reliability analysis were performed. A multigroup analysis in Structural Equation Modeling using AMOS was used to test the proposed hypotheses.

\section{Findings}

Out of 300 responses collected, 25 responses were excluded due to the responses have either more than 10 percent of unanswered items or the same answer to all questions (Hair, Black, Babin, \& Anderson, 2010). A total of 275 valid responses were used for further analysis, representing a response rate of 91.7 percent. An overview of the respondents' profile reveals that the sample is slightly dominated by female respondents (57.3\%). The mean age of the respondents is 27.62 years old and majority of them are in the age range of 20 to 24 years old (41.4\%). A majority of the respondents are Malay (87.3\%). More respondents are studying at the Public Higher Education Institutions (56\%). With respect to program, most of the respondents are taking bachelor degree (70.2\%). Finally, respondents are mostly in their third year of study (44.4\%).

The screening of the data revealed no missing values for all items and all the SEM assumptions were met. Multigroup analysis for the measurement model involves two tests, i.e. examining the adequacy of goodness-of-fit for the model across groups and testing the best-fit model. A good fit model is reflected by a significant chi-square $\left(\chi^{2}\right)$ value, the normed Chi-square value in the range of 1 to 5 , the comparative fit index (CFI) exceed 0.8 and the root mean square error of approximation (RMSEA) below 0.1 (Garson, 2015; Gaskin, 2012; Hair, et al., 2010; Schumacker \& Lomax, 2016). Since this study intends to test the moderating effect, the adequacy of the model was also examined simultaneously and separately by the types of HEls. The results of the confirmatory factor analyses (CFA) of this research (Table 1 ) show a significant chi-square $\left(\chi^{2}\right)$ value at $\alpha=0.05$. Further, the normed $\chi^{2}$, comparative fit index (CFI) and root mean square error of approximation (RMSEA) values meet the acceptable threshold levels of a good fit model, revealing a good fit for all measurement models. 
Table 1: Goodness-of-fit (GOF) Indices

\begin{tabular}{lcccccc}
\hline $\begin{array}{l}\text { Measurement } \\
\text { model }\end{array}$ & $\chi^{\mathbf{2}}$ & DF & P & $\chi^{\mathbf{2} / \mathbf{d f}}$ & CFI & RMSEA \\
\hline Overall & 1347.926 & 601 & 0.000 & 2.243 & 0.908 & 0.071 \\
Simultaneous & 2276.402 & 1231 & 0.000 & 1.849 & 0.875 & 0.058 \\
PublicHEls & 1090.338 & 601 & 0.000 & 1.814 & 0.888 & 0.08 \\
PrivateHEls & 1158.649 & 601 & 0.000 & 1.928 & 0.86 & 0.085 \\
Acceptable value & \multicolumn{7}{c}{ Significant at a $=0.05$} & $1-5$ & $>0.8$ & $<0.1$ \\
\hline
\end{tabular}

After achieving the model fit, the invariance test was conducted. The results as presented in Table 2, shows the chi-square difference value of 27.416 with 29 degree of freedom that is not significant at the 0.05 . Hence, the two models do not differ significantly in their goodnessof-fit. Further, the CFI and RMSEA difference shows a value that is below 0.01 and 0.015 , respectively. Thus, the results indicate that invariant (constraint) model is better fitting than variant (constraint) model. Accordingly, to proceed with the structural model, the invariant model was used.

Table 2: Invariance Test for Measurement Model Results

\begin{tabular}{lccccc}
\hline \multicolumn{1}{c}{ Model } & DF & CMIN & P & CFI & RMSEA \\
\hline Unconstraint & 1202 & 2248.986 & 0 & 0.875 & 0.059 \\
model & & & 0 & 0.875 & 0.058 \\
Constraint model & 1231 & 2276.402 & 0 & 0.000 & 0.001 \\
Difference, $\Delta$ & 29 & 27.416 & 0.549 & $\Delta<0.01$ & $\Delta<0.015$ \\
Acceptable rules & \multicolumn{5}{c}{ significant if $\mathrm{p}<0.05$} \\
\hline
\end{tabular}

Unstandardized regression weighs for both public and private groups are all significant $(p<0.05)$, and standardized regression weights are all above 0.5 , indicating that all constructs are significantly representative by their corresponding items. Further, the critical ratios for differences show no value exceeded \pm 1.96 , indicating no significant difference across groups. Thus, all paths will be constrained to equality in the structural model.

The structural model also shows a good fit to the data as presented in Table 3. Further, the results of the structural test show the chi-square difference and $z$ score values for all paths are not significant ( $p>0.05,< \pm 1.96$ ) across group for types of HEls. Hence, the hypothesized structural relationships operated similarly for both public and private HEls (Figure 2 and Figure 3). Accordingly, all hypotheses ( $\mathrm{H} 1$ to $\mathrm{H} 7$ ) are not supported. 
INTERNATIONAL JOURNAL OF ACADEMIC RESEARCH IN BUSINESS AND SOCIAL SCIENCES Vol. 9, No. 7, July, 2019, E-ISSN: 2222-6990 @ 2019 HRMARS

Table 3: Structural Invariance Test Results

\begin{tabular}{|c|c|c|c|c|c|c|c|c|c|}
\hline & & & \multicolumn{2}{|c|}{ PublicHEls } & \multicolumn{2}{|c|}{ PrivateHEls } & \multirow{2}{*}{$\begin{array}{c}\text { z- } \\
\text { score }\end{array}$} & \multirow{2}{*}{$\Delta \chi^{2}$} & \multirow{2}{*}{$p$} \\
\hline & & & Estimate & $P$ & Estimate & $P$ & & & \\
\hline COM & $<--$ & IEI & -0.489 & 0.015 & -0.465 & 0.001 & 0.1 & 0.01 & 0.922 \\
\hline COM & $\begin{array}{c}<-- \\
-\end{array}$ & ISI & 0.183 & 0.319 & 0.327 & 0.022 & 0.62 & 0.355 & 0.551 \\
\hline COM & $\begin{array}{c}<-- \\
-\end{array}$ & SDI & 0.987 & 0.001 & 0.422 & 0.02 & -1.594 & 2.667 & 0.102 \\
\hline COM & $\begin{array}{c}<-- \\
-\end{array}$ & SII & -0.063 & 0.713 & 0.093 & 0.343 & 0.792 & 0.62 & 0.431 \\
\hline COM & $\begin{array}{c}<-- \\
-\end{array}$ & SAT & 0.543 & 0.002 & 0.646 & 0.001 & 0.393 & 0.147 & 0.701 \\
\hline COM & $\begin{array}{c}<- \\
-\end{array}$ & $A L T$ & 0.001 & 0.986 & 0.072 & 0.214 & 0.746 & 0.503 & 0.478 \\
\hline SE & $\begin{array}{c}<-- \\
-\end{array}$ & COM & 0.826 & $* * *$ & 0.692 & $* * *$ & -0.995 & 0.973 & 0.324 \\
\hline
\end{tabular}

Note:

IEI - Institution Economic Investment, ISI - Institution Social Investment, SDI -

Student Direct Investment, SII - Student Indirect Investment, SAT - Satisfaction, ALT - Alternative Attractiveness, COM - Commitment, SE - Student-institution engagement

${ }^{* * *} p<0.001$

Goodness-of-fit statistics: $\chi^{2}=2287.21(\mathrm{df}=1215, \mathrm{p}=0.000), \chi^{2} / \mathrm{df}=1.882$,

$\mathrm{CFI}=0.872, \mathrm{RMSEA}=0.06$

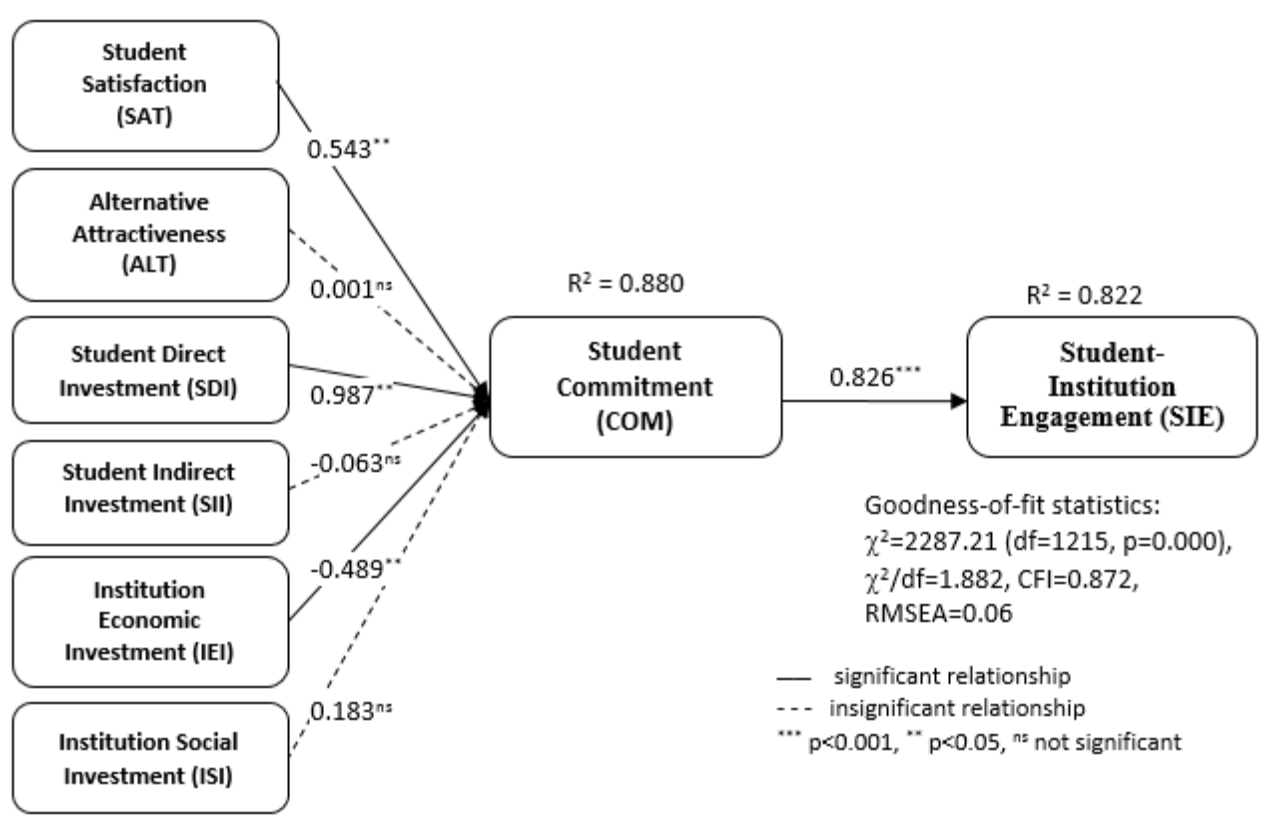

Figure 2: Structural Model for Public HEls 


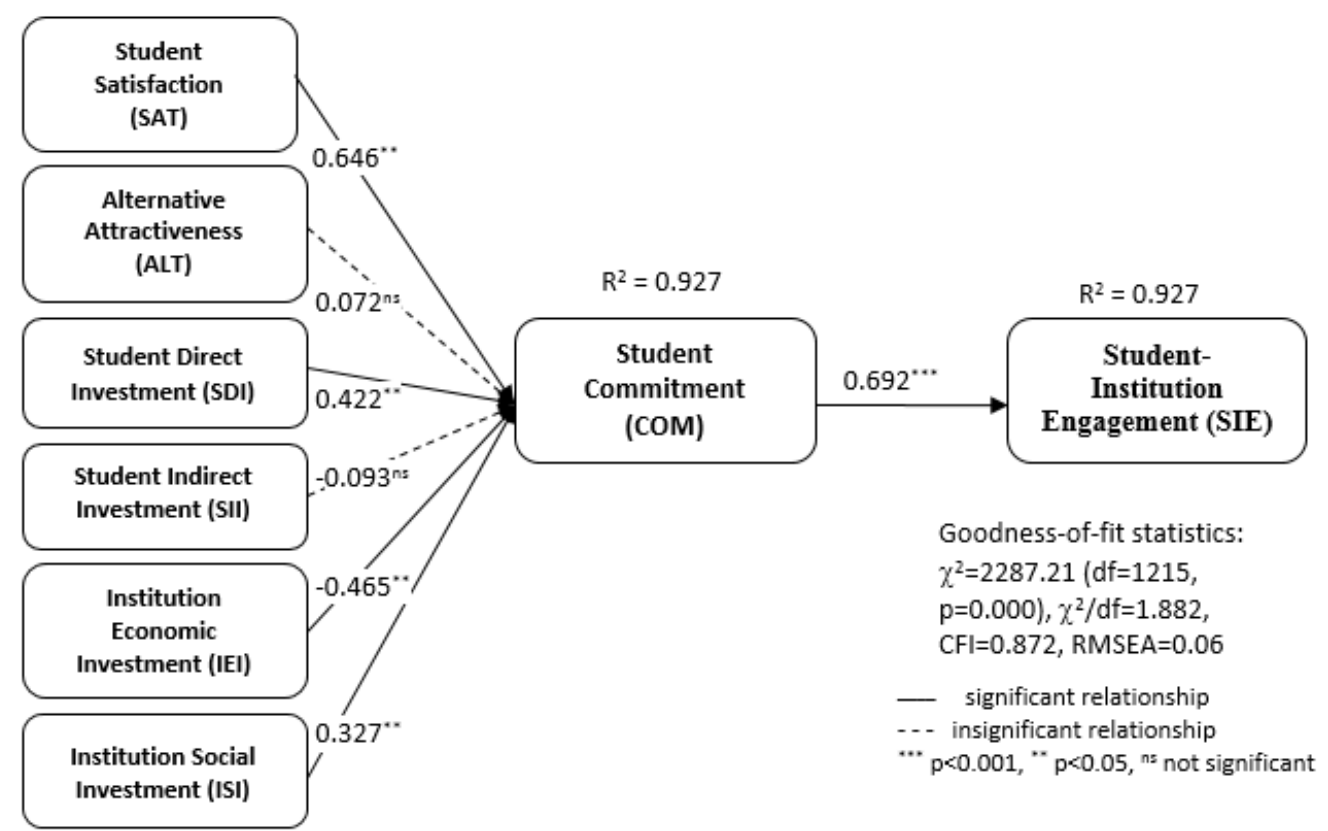

Figure 3: Structural Model for Private HEls

The results reveal that to engage the students, both public and private HEls must increase the student commitment (COM). To gain student commitment (COM), the public and private HEls need to increase the student satisfaction (SAT) as well as student direct investment (SDI). As for the institution economic engagement (IEI), it poses negative effect on student commitment (COM), indicating that institution economic engagement (IEI) needs to be reduced as to increase student commitment (COM). The effect of institution social investment (ISI) on student commitment (COM) is not significant for public HEls. For private HEls, the effect of institution social investment (ISI) on student commitment (COM) is positive but the least compared to other factors. As for student indirect investment (SII) and alternative attractiveness (ALT), both have no significant effect on student commitment (COM).

\section{Conclusions}

Despite operating in different competitive landscape, both the public and private HEls should focus on somewhat similar strategies to achieve a competitive advantage in recruiting, retaining and engaging the students. Basically, to engage the students, both public and private HEls must increase the student commitment. In order to increase the student commitment, public HEls should increase the student satisfaction towards their services, highlight the investment made by students in term of money and efforts, and provoke the level of investment made by the institutions in providing better learning infrastructure. Regarding the private HEls, to provide better learning infrastructure to their students, they should implement the same strategies as mentioned for the public HEls. Nevertheless, the private $\mathrm{HEls}$ should also concentrate on building emotional bond with the students through the academicians and staff.

\section{Acknowledgement}

This research is funded by Universiti Pendidikan Sultan Idris Research Grant (2017-0160-10601) 


\section{References}

Abdul-Ghani, E., Hyde, K. F., \& Marshall, R. (2011). Emic and etic interpretations of engagement with a consumer-to-consumer online auction site. Journal of Business Research, 64(10), 1060-1066. doi: http://dx.doi.org/10.1016/j.jbusres.2010.10.009

Alqahtani, A. A. (2011). Toward a clarification of the concept of relationship marketing. International Journal of Management, 28(2), 585 - 590.

Aurier, P., \& de Lanauze, G. S. (2012). Impacts of perceived brand relationship orientation on attitudinal loyalty: An application to strong brands in the packaged goods sector. European Journal of Marketing, 46(11), 1602 - 1627.

Bajunid, I., and Wong, W. (2016). "Private Higher Education Institutions in Malaysia." In A Global Perspective on Private Higher Education, edited by M. Shah and S. C. Nair, 131155. https://doi.org/10.1016/B978-0-08-100872-0.00008-2

Bhattacherjee, A. (2012). Social Science Research: Principles, Methods, And Practices (2nd edition ed.). Zurich, Switzerland: Creative Commons Attribution.

Bolton, R. N., Smith, A. K., \& Wagner, J. (2003). Striking the Right Balance: Designing Service to Enhance Business-to-Business Relationships. Journal of Service Research, 5(4), 271291. doi: $10.1177 / 1094670503005004001$

Bowden, J. L. (2007). Segmenting customer-brand relationships : the process of customer engagement. Paper presented at the Australian and New Zealand Marketing Academy Conference (ANZMAC), Dunedin, New Zealand. http://hdl.handle.net/1959.14/71153

Bowden, J. L. (2009a). Customer Engagement: A Framework for Assessing Customer-Brand Relationships: The Case of the Restaurant Industry. Journal of Hospitality Marketing \& Management Decision, 18(6), 574-596. doi: http://dx.doi.org/10.1080/19368620903024983

Bowden, J. L. (2009b). The Process of Customer Engagement: A Conceptual Framework. Journal of Marketing Theory and Practice, 17(1), 63-74. doi: 10.2753/MTP10696679170105

Breivik, E., \& Thorbjornsen, H. (2008). Consumer brand relationships: an investigation of two alternative models. Journal of the Academy of Marketing Science, 36(4), 443-472.

Brodie, R. J., \& Hollebeek, L. D. (2011). Response: Advancing and Consolidating Knowledge About Customer Engagement. Journal of Service Research, 14(3), 283-284. doi: $10.1177 / 1094670511415523$

Brodie, R. J., Hollebeek, L. D., Juric, B., \& Ilic, A. (2011). Customer Engagement: Conceptual Domain, Fundamental Propositions, and Implications for Research. Journal of Service Research, 14(3), 252-271. doi: 10.1177/1094670511411703

Carter, T. (2008). Customer Engagement and Behavioral Considerations. Journal of Strategic Marketing, 16(1), 21-26. doi: 10.1080/09652540701794387

Cheung, C. M. K., Lee, M. K. O., \& Jin, X.-L. (2011). Customer Engagement in an Online Social Platform: A Conceptual Model and Scale Development. Paper presented at the 32nd International Conference on Information Systems (ICIS) 2011, Shanghai International Convention Centre, Shanghai, China.

http://aisel.aisnet.org/icis2011/proceedings/onlinecommunity/8/

Circles. (2010). Turning Emotion into Engagement: Utilizing the power of emotion to connect customers to your brand. Retrieved from http://www.circles.com/docs/CE\%20Whitepaper_Engagement_071410.pdf 
Creswell, J. W. (2009). Research Design: Qualitative, Quantitative and Mixed Method Approaches (3rd edition ed.). California: SAGE Publications, Inc.

Wulf, D. K., \& Odekerken-Schroder, G. (2001). The Influence of Seller Relationship Orientation and Buyer Relationship Proneness on Trust, Commitment, and Behavioral Loyalty in a Consumer Environment. Journal for the Theory of Social Behaviour, 31(1), 1-27.

Wulf, D. K., Odekerken-Schroder, G., \& Kenhove, P. V. (2003). Investments in consumer relationships: A critical reassessment and model extension. The International Review of Retail, Distribution and Consumer Research, 13(3), 245-261.

Dorsch, M. J., Carison, L., Raymond, M. A., \& Ranson, R. (2001). Customer Equity Management and Strategic Choices for Sales Managers. [Article]. Journal of Personal Selling \& Sales Management, 21(2), 157 - 166.

Flynn, L. M. (2012). An Exploration of Engagement: A Customer Perspective. Doctor of Philosophy, DePaul University, Chicago, Illinois. Retrieved from http://via.library.depaul.edu/csh_etd/8

Forbes. (2010). The New Rules of Engagement: CMOs Rethink Their Marketing Mix. Retrieved from

http://www.forbes.com/forbesinsights/engagement/index.html

Forrester. (2008). How Engaged Are Your Customers? Forrester Consulting Report. Retrieved from

http://www.adobe.com/engagement/pdfs/Forrester_TLP_How_Engaged_Are_Your_ Customers.pdf

Fullerton, G. (2011). Creating advocates: The roles of satisfaction, trust and commitment. Journal of Retailing and Consumer Services, 18(2011), 92-100. doi: 10.1016/j.jretconser.2010.10.003

Garson, G. D. (2015). Structural Equation Modeling. Asheboro, NC USA: Statistical Associates Publishing.

Gaskin, J. (2012). Confirmatory Factor Analysis. Gaskination's StatWiki. Retrieved from http://statwiki.kolobkreations.com

Ginman, C. (2011). [en-geyj-muh nt]: How are Brands Engaging and Building Relationships with Fans and Customers in Social Media? Media and Communication Studies Independent thesis Advanced level (degree of Master), Uppsala University, Uppsala, Sweden. Retrieved from http://urn.kb.se/resolve?urn=urn:nbn:se:uu:diva-154320

Goodfriend, W., \& Agnew, C. R. (2008). Sunken Costs and Desired Plans: Examining Different Types of Investments in Close Relationships. Personality and Social Psychology Bulletin, 34(12), 1639-1652. doi: 10.1177/0146167208323743

Hair, J. F., Black, W. C., Babin, B. J., \& Anderson, R. E. (2010). Multivariate Data Analysis: A global perspective (7th edition ed.). Upper Saddle River, New Jersey: Pearson Education Inc.

Han, H., Kim, W., \& Hyun, S. S. (2011). Switching intention model development: Role of service performances, customer satisfaction, and switching barriers in the hotel industry. International Journal of Hospitality Management, 30(3), 619-629. doi: 10.1016/j.ijhm.2010.11.006

Haven, B. (2007). Marketing's New Key Metric: Engagement Forrester Research Report. Retrieved from

http://www.adobe.com/engagement/pdfs/marketings_new_key_metric_engageme nt.pdf 
Haven, B., \& Vittal, S. (2008). Measuring Engagement. Forrester Research Reports. Retrieved from http://www.adobe.com/engagement/pdfs/measuring_engagement.pdf

Hess, J., \& Story, J. (2005). Trust-based commitment: multidimensional consumer-brand relationships. Journal of Consumer Marketing, 22(6), 313-322.

Hollebeek, L. D. (2009). Demystifying Customer Engagement: Toward the Development of a Conceptual Model Paper presented at the Australian \& New Zealand Marketing Academy (ANZMAC), Crown Promenade, Melbourne, Australia. http://www.duplication.net.au/ANZMAC09/papers/ANZMAC2009-010.pdf

Huang, L. T., Cheng, T. C., \& Farn, C. K. (2007). The Mediating Effect of Commitment on Customer Loyalty towards E-Brokerages: An Enhanced Investment Model. Total Quality Management, 18(7), 751-770.

Kim, H.-Y., Kim, Y.-K., Jolly, L., \& Fairhurst, A. (2008). Satisfied Customers' Love toward Retailers: A Cross-Product Exploration. Advances in Consumer Research, 35(2008), 507-515.

Le, B., \& Agnew, C. R. (2003). Commitment and its theorized determinants: A meta-analysis of the Investment Model. Personal Relationships, 10(2003), 37-57.

Li, X. R., \& Petrick, J. F. (2008). Examining the Antecedents of Brand Loyalty From an Investment Model Perspective. Journal of Travel Research, 47(1), 25-34. doi: $10.1177 / 0047287507312409$

Louis, D., \& Lombart, C. (2010). Impact of brand personality on three major relational consequences (trust, attachment, and commitment to the brand). Journal of Product \& Brand Management, 19(2), 114-130. doi: 10.1108/10610421011033467

MacKenzie, S. B., \& Podsakoff, P. M. (2012). Common Method Bias in Marketing: Causes, Mechanisms, and Procedural Remedies. Journal of Retailing, 88(4), 542-555. doi: http://dx.doi.org/10.1016/j.jretai.2012.08.001

Malciute, J. (2012). Customer Brand Engagement on Online Social Media Platforms: A Conceptual Model and Empirical Analysis. Master of Science in Marketing Master Thesis, Aarhus University, Aarhus. Retrieved from http://pure.au.dk/portal-asbstudent/files/48031171/Thesis_FINAL.pdf

Malhotra, N., Krosnick, J. A., \& Thomas, R. K. (2009). Optimal Design Of Branching Questions To Measure Bipolar Constructs. Public Opinion Quarterly, 73(2), 304-324. doi: 10.1093/poq/nfp023

Malhotra, N. K. (Ed.). (2009). Basic Marketing Research: A decision making approach (3rd edition ed.). New Jersey: Prentice Hall.

Ministry of Education Malaysia. (2014). National Education Statistic : Higher Education Sector 2013 Retrieved from http://www.mohe.gov.my/web_statistik/Perangkaan-2013.pdf

Ministry of Education Malaysia (2017). Higher Education Statistics 2017. Retrieved from http://mohe.gov.my/en/download/awam/statistik/2017-3

Ministry of Higher Education Malaysia. (2007). The National Higher Education Action Plan 2007-2010. Putrajaya: Kementerian Pengajian Tinggi Malaysia.

Moon, M. A., \& Bonney, L. (2007). An application of the investment model to buyer-seller relationships: a dyadic perspective. Journal of Marketing Theory and Practice, 15(4), 335-347. doi: 10.2753/MTP1069-6679150404

Morais, D. B., Backman, S. J., \& Dorsch, M. J. (2003). Toward the Operationalization of Resource Investments Made between Customers and Providers of a Tourism Service. Journal of Travel Research, 41(4), 362-374. doi: 10.1177/0047287503041004005 
Morais, D. B., Dorsch, M. J., \& Backman, S. J. (2004). Can Tourism Providers Buy their Customers' Loyalty? Examining the Influence of Customer-Provider Investments on Loyalty. Journal of Travel Research, 42(3), 235-243. doi: 10.1177/0047287503258832

Nusair, K. K., Parsa, H. G., \& Cobanoglu, C. (2011). Building a model of commitment for Generation Y: An empirical study on e-travel retailers. Tourism Management, 32(2011), 833-843. doi: 10.1016/j.tourman.2010.07.008

Nysveen, H., Pedersen, P. E., Thorbjornsen, H., \& Berthon, P. (2005). Mobilizing the Brand: The Effects of Mobile Services on Brand Relationships and Main Channel Use. Journal of Service Research, 7(3), 257-276. doi: 10.1177/1094670504271151

Odekerken-Schroder, G., De Wulf, K., \& Schumacherc, P. (2003). Strengthening outcomes of retailer-consumer relationships: The dual impact of relationship marketing tactics and consumer personality. Journal of Business Research, 56(3), 177- 190. doi: http://dx.doi.org/10.1016/S0148-2963(01)00219-3

Peoplemetrics. (2009). Most Engaged Customers (MEC) Study (2009). Retrieved from http://www.peoplemetrics.com/resources/2009_MEC_WhitePaper.pdf

Rappaport, S. D. (2007). Lessons from Online Practice: New Advertising Models. [Article]. Journal of Advertising Research, 47(2), 135-141. doi: 10.2501/s0021849907070158

Roberts, C., \& Alpert, F. (2010). Total customer engagement: designing and aligning key strategic elements to achieve growth. Journal of Product \& Brand Management, 19(3), 198-209. doi: 10.1108/10610421011046175

Rusbult, C. E. (1980). Commitment and satisfaction in romantic associations: A test of the investment model. [doi: 10.1016/0022-1031(80)90007-4]. Journal of Experimental Social Psychology, 16(2), 172-186.

Rusbult, C. E. (1983). A Longitudinal Test of the Investment Model: The Development (and Deterioration) of Satisfaction and Commitment in Heterosexual Involvements. Journal of Personality and Social Psychology, 45(1), 101-117.

Rusbult, C. E., Martz, J. M., \& Agnew, C. R. (1998). The Investment Model Scale: Measuring commitment level, satisfaction level, quality of alternatives, and investment size. Personal Relationships, 5(4), 357-387. doi: 10.1111/j.1475-6811.1998.tb00177.x

Sashi, C. M. (2012). Customer engagement, buyer-seller relationships, and social media. Management Decision, 50(2), 253-272. doi: 10.1108/00251741211203551

Saunders, M., Lewis, P., \& Thornhill, A. (2009). Research methods for business students (5th edition ed.). Essex: Pearson Education Limited.

Scholer, A. A., \& Higgins, E. T. (2009). Exploring the complexities of value creation: The role of engagement strength. Journal of Consumer Psychology, 19(2), 137-143. doi: http://dx.doi.org/10.1016/j.jcps.2009.02.007

Schumacker, R. E., \& Lomax, R. G. (2016). A Beginner's Guide to Structural Equation Modeling (4th ed.). New York: Routledge.

Sedley, R. (2010). 4th Annual Online Customer Engagement Report. Retrieved from http://www.slideshare.net/richardsedley/4th-annual-online-customer-engagementsurvey-report-2010

Sekaran, U., \& Bougie, R. (2016). Research Methods for Business: A Skill Building Approach (7th ed.). West Sussex, UK: John Wiley \& Sons Ltd.

Shi, G., Shi, Y., Chan, A. K. K., Liu, M. T., \& Fam, K.-S. (2011). The role of renqing in mediating customer relationship investment and relationship commitment in China. [doi: 
10.1016/j.indmarman.2010.12.005]. Industrial Marketing Management, 40(4), 496502.

Shukla, P. (2008). Essentials of Marketing Research Retrieved from www.bookboon.com

Singh, A., Kumar, B., \& Singh, V. K. (2010). Customer Engagement: New Key Metric of Marketing. International Journal of Arts and Sciences, 3(13), 347 - 356.

Sung, Y., \& Campbell, W. K. (2009). Brand commitment in consumer-brand relationships: An investment model approach. Brand Management, 17(2), 97-113.

Sung, Y., \& Choi, S. M. (2010). I won't leave you although you disappoint me: The interplay between satisfaction, investment and alternatives in determining consumer-brand relationship commitment. Psychology \& Marketing, 27(11), 1050-1074.

Tripathi, M. N. (2009). Customer Engagement - Key to Successful Brand Building. Vilakshan, XIMB Journal of Management, 6(1), 131-140.

van Doorn, J., Lemon, K. N., Mittal, V., Nass, S., Pick, D., Pirner, P., \& Verhoef, P. C. (2010). Customer Engagement Behavior: Theoretical Foundations and Research Directions. Journal of Service Research, 13(3), 253-266. doi: 10.1177/1094670510375599

Verhoef, P. C., Reinartz, W. J., \& Krafft, M. (2010). Customer Engagement as a New Perspective in Customer Management. Journal of Service Research, 13(3), 247-252. doi: $10.1177 / 1094670510375461$

Voyles, B. (2007). Beyond loyalty: Meeting the challenge of customer engagement. In R. Ramaswami (Ed.), The Economist. London: Economist Intelligence Unit.

Wang, F., \& Head, M. (2007). How can the Web help build customer relationships? Information \& Management, 44(2), 115-129. doi: 10.1016/j.im.2006.10.008

$\mathrm{Yu}, \mathrm{Y}$. (2015). Relationship investment and reciprocity: an empirical investigation. Journal of Business \& Industrial Marketing, 30(5), 637-647. doi: doi:10.1108/JBIM-11-2013-0246

Zainol, Z. (2015). Rethinking Customer Engagement In Customer-Brand Relationship Context. Paper presented at the National Research Seminar (SPK2015) E-learning Building, Universiti Pendidikan Sultan Idris

Zikmund, W. G., \& Babin, B. J. (2006). Exploring Marketing Research. Mason, Ohio: Thomson South-Western. 